\title{
CORAL SNAKE ANTIVENOM PRODUCED IN CHICKENS (Gallus domesticus)
}

\author{
Irma AGUILAR(1) ${ }^{\S}$, Elda E. SÁNCHEZ(2) ${ }^{\S}$, María E. GIRÓN(1,3), Amalid ESTRELLA(1,3), Belsy GUERRERO(4) \& F. Alexis RODRIGUEZ-ACOSTA(1,3)
}

\begin{abstract}
SUMMARY
The production of anti-snake venom from large mammal's blood has been found to be low-yielding and arduous, consequently, antivenom immunoglobulins for treatment are achieved regularly as polyvalent serum. We have standardized an undemanding technique for making purified immunoglobulin IgY antivenom consisting of polyclonal antibodies against coral snake venom in the egg yolk of immunized hens. We have adapted a reported process of antibody purification from egg yolks, and achieved $90 \%$ antibody purity. The customized technique consisted of the removal of lipids from distilled water-diluted egg yolks by a freeze-thaw sequence. The specific immunoglobulins were present in the egg yolk for up to 180 days postimmunization. Therefore, by means of small venom quantities, a significant amount of immunoglobulins were found in an adequately purified state (The obtained material contained about $90 \%$ pure IgY). The antigen binding of the immunoglobulins was detected by a double immunodiffusion test. Titers of antibodies in the yolk were estimated with a serum protection assay (Median effective dose $\left.=E_{50}\right)\left(E_{50}=477 \mathrm{mg} / \mathrm{kg}\right)$. Given that breeding hens is economically feasible, egg gathering is noninvasive and the purification of $\operatorname{IgY}$ antibodies is quick and easy, chicken immunization is an excellent alternative for the production of polyclonal antibodies. To the best of our knowledge, this is the first coral snake antivenom prepared in birds.
\end{abstract}

KEYWORDS: Coral antivenom; Elapidae; IgY immunoglobulins; Micrurus; venom.

\section{INTRODUCTION}

Snake envenomation produces tissue effects such as local swelling and necrosis, neurotoxicity and hemostatic disorders. Considerable advancement has been made in understanding the pathophysiology of ophidic accidents, motivating transformations in treatment procedures. Latest advances, including the production of new antivenoms using new processes $^{1-4,19}$, have encouraged developing coral snake antivenoms with attractive protocols.

Nearly two hundred species from the Elapidae family are dispersed across the Southeastern and Southwestern United States, as well as all of Mexico, Central America and South America, and are also established in the African, Asian and Oceanic continents ${ }^{3}$. On the American continent, more than 120 species and subspecies have been described, separated into three genera: Leptomicrurus with three species, Micruroides, with one, and Micrurus, with approximately 70 species $^{21,22}$.

The production of safe, efficient and reasonably priced antivenoms is a priority. Alternative progress in the therapeutics of coral snake bite victims in Venezuela requires an answer to the production of new animal models, logistical, financial, marketing, delivery and storage difficulties related to the supply of antivenom. Furthermore, the norms and regulations for physicians to improve antivenom use must also be addressed. Even though coral snake envenomations could be handled using medications that act on presynaptic and postsynaptic receptors, since some patients may only survive under intensive therapy treatment such as respiratory support $\mathrm{t}^{23}$, specific treatment with antivenoms continues to be the elected method for treating these incidents, which can efficiently deactivate all systemic activities of the venom. Nevertheless, there are some collateral effects of antivenom such as anaphylaxis and serum sickness ${ }^{5}$. The majority of these alterations seem to be caused by the action of high concentrated proteins, which are not immunoglobulins, but contaminating polyvalent antivenoms. However, the benefits of antivenom treatment may be more important than its risks.

The specific therapeutics for coral snake envenomations is the use of heterologous antivenom, and to date, this type of antivenom is not available in Venezuela. In light of the information that coral snake venom can reveal a multiplicity of composition and toxic activities, we have included the most important venom species occurring in Venezuela and United States in the immunization protocol. At this time, we present a study on the production of a specific coral snake (Micrurus) antivenom and its purification of immunoglobulins from the egg yolk of immunized hens, with the purpose of providing a more efficient antivenom for therapeutic treatments.

(1) Immunochemistry Section, Tropical Medicine Institute, Universidad Central de Venezuela, Caracas, Venezuela.

(2) National Natural Toxins Research Center and the Department of Chemistry, Texas A\&M University-Kingsville, Kingsville, Texas, U.S.A.

(3) Sección de Ultraestructura Toxinológica, Instituto Anatómico, Universidad Central de Venezuela, Caracas, Venezuela.

(4) Laboratorio de Fisiopatología, Centro de Medicina Experimental, Instituto Venezolano de Investigaciones Científicas (IVIC), Caracas, Venezuela.

${ }^{\S}$ Authors contributed equally to this work.

Correspondence to: Alexis Rodríguez-Acosta MD Ph.D. Apartado 47423, Caracas 1041, Venezuela. Tel: +58-416-3333361. E-mail: rodriguezacosta1946@ yahoo.es 
AGUILAR, I.; SÁNCHEZ, E.E.; GIRÓN, M.E.; ESTRELLA, A.; GUERRERO, B. \& RODRIGUEZ-ACOSTA, F.A. - Coral snake antivenom produced in chickens (Gallus domesticus). Rev. Inst. Med. Trop. Sao Paulo, 56(1): 61-6, 2014.

\section{MATERIALS AND METHODS}

Ethical statement: All the experimental events concerning the use of live animals were carried out by specialized staff. The relevant regulations of Venezuela as well as institutional guidelines, according to protocols approved by the Institute of Anatomy of the Universidad Central de Venezuela, and the norms obtained from the guidelines for the care and use of laboratory animals ${ }^{13}$ were followed.

Coral snakes (Micrurus) venom: Venom from a collection (twenty specimens) of different Micrurus species from Venezuela and the United States were used in the immunization protocol. The venom of Venezuelan coral snakes consisted of (Micrurus isozonus (Calabozo, Guárico State), Micrurus isozonus (Caracas, D.C), Micrurus isozonus (La Boyera, Miranda State), and Micrurus isozonus (Maracay, Aragua State) which were supplied by the Serpentarium of the Tropical Medicine Institute of the Universidad Central de Venezuela, Caracas, Venezuela. The venom from the U.S. consisted of Micrurus fulvius fulvius (Eastern, USA), and Micrurus tener tener (Western, USA), purchased from the National Natural Toxins Research Center, Texas A\&M University-Kingsville, Kingsville, Texas, USA.

Fifteen days prior to venom extraction, the coral snakes were fed and made to fast to guarantee enough venom in their glands. The venom was collected through a 50-mL plastic centrifuge tube transversely cut and covered on the top with Parafilm ${ }^{\circledR}$ (Millipore Corp, USA). The snake was forced to bite the Parafilm. Venom was collected by glass capillaries through the excretory conduit in the base of the fangs, centrifuged, and supernatants were placed in Eppendorf® (Eppendorf Int, USA) tubes and stored at $-30{ }^{\circ} \mathrm{C}$ until use. Stock solutions were prepared in phosphatebuffered saline (PBS) (10 Mm sodium phosphate containing $150 \mathrm{Mm}$ $\mathrm{NaCl}, \mathrm{Ph} 7.2)$ at $1.0 \mathrm{mg} / \mathrm{mL}$.

Mice: Female mice (INH strain) weighing 18-20 g were obtained from the Instituto Nacional de Higiene "Rafael Rangel", Caracas, Venezuela. The colony of mice was kept in plastic boxes (Tecniplast, Italy) at six mice per cage, in a room maintained at $23{ }^{\circ} \mathrm{C}$ on a $12 / 12-\mathrm{hr}$ light/dark cycle.

Hens: Six egg-laying, red hens (Gallus domesticus) of Rhode Island strain, approximately 16 weeks old, obtained from a poultry farm from Lagunita town, Miranda State, Venezuela, were located in individual henhouses (Centenosuplidores C.A, Venezuela)(one hen per henhouse) prior to the commencement of the production of eggs. Hens were maintained on 12/12-hr light/dark cycle at $23{ }^{\circ} \mathrm{C}$ with food and water ad libitum.

Determination of protein concentration: Protein determination was established by the method of LOWRY et al. ${ }^{15}$.

Micrurus' venom lethality: Lethality of crude venom was determined by intravenous injections into mice and the $\mathrm{LD}_{50}$ value calculated according to the Spearman-Karber method ${ }^{31}$. The venom was diluted in a phosphate-buffered saline solution (PBS). The endpoint of lethality of the mice was determined after $48 \mathrm{~h}$. All solutions during the experiments were stored at $4{ }^{\circ} \mathrm{C}$ and warmed to $37{ }^{\circ} \mathrm{C}$ prior to being injected into mice. The lethal toxicity was determined in five groups containing five mice. A total of $0.2 \mathrm{~mL}$ of venom (dosages from 0.05 to
$0.8 \mathrm{mg} / \mathrm{kg}$ ) was injected into the tail vein of $18-20 \mathrm{~g}$ female BALB/c mice. A comparable volume of PBS was injected as a negative control group.

Sodium dodecyl sulphate-polyacrylamide gel electrophoresis (SDS-PAGE) of coral snake's crude venom: Pools of different coral snakes' crude venom under non-reduced conditions were electrophoresed using a MINIPROTEAN II (BioRad, USA) chamber. SDS-PAGE was performed according to the Laemmli method (1970) ${ }^{14}$ using $15 \%$ gels. Wide range molecular weight markers (Bio-Rad) were run in parallel and gels were stained with Comassie blue (National Diagnostic, USA).

Immunization: A pool was made with concentrations of venom, corresponding to the $\mathrm{LD}_{50}$ median. A sub-lethal dose was used for immunizations. Four-month-old egg-laying hens, weighing $\sim 1 \mathrm{~kg}$ were maintained pathogen-free and immunized with the pool of coral snakes' venom. Venom $(0.24 \mathrm{mg} / \mathrm{kg}$ in $0.1 \mathrm{~mL})$ was taken into an Eppendorf tube and then mixed with an equal volume of Freund's complete adjuvant, whereas the second doses consisted of venom emulsified with Freund's incomplete adjuvant (GIBCO, USA). The third venom doses were mixed with a saline solution. All doses were administered subcutaneously, via the deltoid region in four different places, alternating right and left every two weeks for eight weeks. One week after the last dose, the hens' blood was obtained for the detection of immunoglobulins that could recognize and precipitate the coral snake venom.

Isolation of immunoglobulin: The modified method of SVENDSON et al. $(1995)^{30}$ using the freeze and thaw principle to remove lipids was used. For a brief period, the egg yolk was diluted 10 times with distilled water, and the diluted egg yolk was frozen at $-80{ }^{\circ} \mathrm{C}$ overnight, and permitted to thaw at an increased temperature rate of $\sim 2{ }^{\circ} \mathrm{C}$ ( $\operatorname{six}$ min) by maintaining it at $2-4{ }^{\circ} \mathrm{C}$. The egg yolk was then centrifuged at $18,000 \mathrm{~g}$ for $1 \mathrm{~h}$ at $4{ }^{\circ} \mathrm{C}$ and the supernatant gathered was cleared by filtration on Whatman $\left(\mathrm{N}^{\circ}\right.$. 1) filter paper (Whatman, USA). To precipitate the immunoglobulins, the filtered supernatant was then precipitated by $40 \%$ ammonium sulfate at 4 ${ }^{\circ} \mathrm{C}$. Afterwards, the pellet was re-suspended in $0.01 \mathrm{M}$ Tris- $\mathrm{HCl}(\mathrm{pH} 8.0)$ to a volume equal to half of the supernatant. Following centrifugation for $15 \mathrm{~min}$ at $13000 \mathrm{~g}$, the pellet was washed twice with $40 \%$ ammonium sulfate (ReAgent, UK). The solution was dialyzed carefully (three buffer changes, at least 150 times volume) against $10 \mathrm{mM}$ phosphate buffer, $\mathrm{pH}$ 7.0 , for 24 to $48 \mathrm{~h}$ in a dialyzing tube with molecular cut off weight of 14 KDa to remove the ammonium sulfate $e^{5,19}$.

Antibody activity and purity were determined using a SDS-PAGE ${ }^{14}$, double gel diffusion test ${ }^{18}$ and a serum protection test $\left(\mathrm{ED}_{50}\right)$, respectively.

Gel diffusion assay using specific IgY against coral snake venom: To show the specific IgY immunoglobulin activity, a 1\% agarose (SigmaAldrich Co. USA) double gel diffusion test was used ${ }^{18}$. The immunizing pool of coral snake crude venom at $10 \mathrm{mg} / \mathrm{mL}$ was placed in the central well, while different coral snake venoms and PBS were placed in the outer wells and incubated at $37^{\circ} \mathrm{C}$.

Serum protection test $\left(\right.$ Median effective dose $=\mathbf{E D}_{50}$ ): For antivenom effectiveness, five groups of eight mice were challenged with a mixture of varying concentrations of $\mathrm{IgY}$ antivenom containing three $\mathrm{LD}_{50}$ of venom. The antivenom/venom mixture was prepared at $0{ }^{\circ} \mathrm{C}$ and incubated for $30 \mathrm{~min}$ at $37^{\circ} \mathrm{C}$ prior to injection. Each mouse was injected with $0.2 \mathrm{~mL}$ of venom/antivenom mixture into the tail vein. The mice were observed 
for $48 \mathrm{~h}$ and the survival percentage and $\mathrm{ED}_{50}$ were calculated according to Spearman and Karber ${ }^{31}$. Saline controls and antivenom controls were used. Neutralizing capability was expressed as the $50 \%$ effective dose (the amount of antivenom that protects $50 \%$ of the population) (Table 2).

Specificity of coral snake antivenom (IgY) to various snake venom via Western blot: To explore the specificity of the immunoglobulins against coral snake venom, the antibodies were also assayed with Crotalus and Bothrops venom. A total of nine venom (22 $\mu$ g/each) consisting of M. isozonus, M. surinamensis, M.f. fulvius, M. t. tener, Naja kaouthia, Naja pallida, Bothrops colombiensis, Crotalus durissus cumanensis and $C$. vegrandis were electrophoresed on a 10-20\% Tricine SDS gel using a XCell SureLock ${ }^{\mathrm{TM}}$ system at 150V (Bio-Rad PowerPac Basic) for one hour. The proteins were transferred onto a $0.2 \mu \mathrm{m}$ nitrocellulose membrane (Millipore) using a Trans Blot SD system (BioRad) at 100 $\mathrm{mA}$ for one hour. The primary antibody (chicken anti-coral snake venom IgY) was diluted to $1 / 200$, the secondary antibody (rabbit anti-chicken IgY-alkaline phosphatase) (Sigma-Aldrich Co. USA) was diluted to 1/50,000. SIGMA FAST TM BCIP/NBT tablets were used to visualize the bands on the blot and SimplyBlue (Life Technologies, USA) was used to visualize the bands on the gel. SeeBluePlus2 (Life Technologies, USA) markers were used as standards.

Antivenom: The antivenom passed the standard tests for neutralizing potency, miocrobiological purity, lack of pyrogenicity, appropriate protein concentration, lack of abnormal toxicity, sterility, and $\mathrm{pH}(6.9)^{11 .}$

\section{RESULTS}

Lethality assay: The $\mathrm{LD}_{50}$ calculated as a median from the mixture of coral snake venom used for immunization was $0.58 \mathrm{mg} / \mathrm{kg}$. The $\mathrm{LD}_{50}$ values were different among Micrurus venoms tested, with $\mathrm{LD}_{50}$ of 0.32 $\mathrm{mg} / \mathrm{kg}$ (Micrurus fulvius), $0.5 \mathrm{mg} / \mathrm{kg}$ (Micrurus isozonus) and $0.78 \mathrm{mg} /$ $\mathrm{kg}$ (Micrurus tener) (Table 1).

\section{Table 1}

$\mathrm{LD}_{50} \mathrm{~s}$ of Venezuelan and United States coral snake venoms. Lethality of crude venom was determined by intravenous injections into mice and the $\mathrm{LD}_{50}$ value calculated according to Spearman-Karber method ${ }^{31}$

\begin{tabular}{lcc}
\hline Species & Pool & $\mathrm{LD}_{50}{ }^{\mathrm{a}} \pm \mathrm{SD}$ \\
\hline M. isozonus & $\begin{array}{c}\text { La Boyera, Miranda } \\
\text { State (Venezuela) }\end{array}$ & $0.5 \pm 0.012$ \\
M. isozonus & $\begin{array}{c}\text { Caracas, Capital } \\
\text { District (Venezuela) } \\
\text { Calabozo, Guárico }\end{array}$ & $0.5 \pm 0.012$ \\
M. isozonus & $\begin{array}{c}\text { State (Venezuela) } \\
\text { Maracay, Aragua State } \\
\text { M. isozonus }\end{array}$ & $0.8 \pm 0.016$ \\
M. tener tener & $\begin{array}{c}\text { Kingsville, Texas State } \\
\text { (United States) }\end{array}$ & $0.78 \pm 0.14$ \\
M. fulvius & $\begin{array}{c}\text { Tampa, Florida State } \\
\text { (United States) }\end{array}$ & $0.32 \pm 0.12$ \\
\hline
\end{tabular}

a $T$ he $\mathrm{LD}_{50}$ is the concentration of venom required to kill $50 \%$ of a mouse population after $48 \mathrm{~h}$. Results are expressed in $\mathrm{mg}$ venom $/ \mathrm{kg}$ body weight. Mean $\mathrm{LD}_{50}=0.58(\mathrm{mg} / \mathrm{kg})$.
Immunization: The $\mathrm{LD}_{50} \mathrm{~s}$ for the venoms were carried out according to the SÁNCHEZ et al. ${ }^{23}$ method. A sub-lethal dose of the pool of venoms made with concentrations corresponding to the $\mathrm{LD}_{50}$ median of $0.3 \mathrm{mg}$ / $\mathrm{kg}$, was used to immunize the hens (Table 1).

Sodium dodecyl sulphate-polyacrylamide gel electrophoresis (SDS-PAGE) of coral snake crude venom: The SDS-PAGE (15\%) protein profiles of Micrurus isozonus venoms were analyzed. The individual venom differed in composition, quantity and intensity of bands (Fig. 1). The M. isozonus venom from Calabozo contained more protein bands above $31 . \mathrm{kDa}$ (Fig. 1; lane 2) than all other M. isozonus venom. The $M$. isozonus venom from Caracas and Maracay both contained a similar protein band between 66.2 and $97.4 \mathrm{kDa}$ (Fig. 1; lanes 3 and 5, respectively). The sample from La Boyera (Fig. 1; lane 4) contained all protein bands below $21.5 \mathrm{kDa}$.

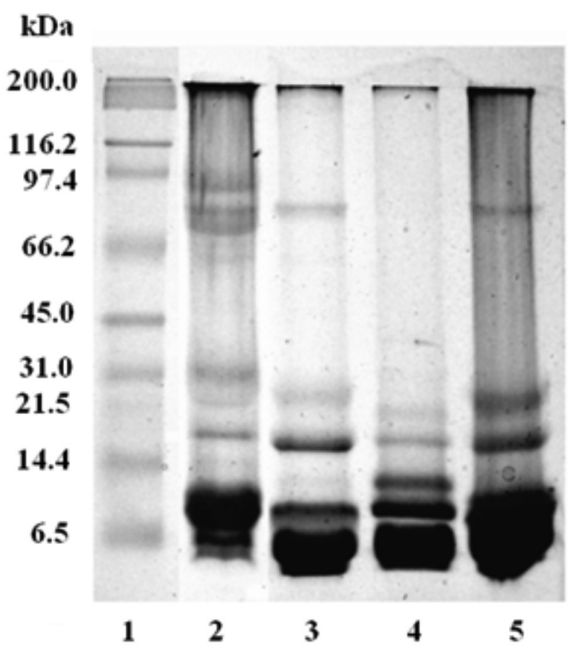

Fig. 1 - SDS-polyacrylamide gel electrophoresis (15\%) of individual M. isozonus venoms from Venezuela. A total of $20 \mu \mathrm{g}$ of venom sample was applied to the gel. Lanes: 1) Markers; 2) M. isozonus (Calabozo); 3) M. isozonus (Caracas); 4) M. isozonus (La Boyera); 5) M. isozonus (Maracay). The gel was stained with Comassie blue.

Isolation of immunoglobulin: This method ${ }^{30}$ involved a gently synchronized $-70{ }^{\circ} \mathrm{C}$ freeze and $4{ }^{\circ} \mathrm{C}$ thaw cycle, consequently giving a clear egg yolk solution. The total protein concentration in one egg yolk was around $1.3 \pm 0.5 \mathrm{~g}$. In this method, a larger component of the additional proteins was excluded through lipid elimination of egg yolk by the freeze and thaw cycle. IgY was reduced with $\beta$-Mercaptoethanol (Sigma-Aldrich Co. USA) showing a heavy chain fragment of $68 \mathrm{kDa}$ and light chain of $27 \mathrm{kDa}$ (Fig. 3). The material, after precipitation, contained about $90 \%$ pure IgY.

Gel diffusion assay using specific IgY against coral snake venom: The existence of antivenom IgY in egg yolk was tested by Ouchterlony's immunodiffusion assay ${ }^{18}$ using crude venom as the antigen (Fig. 2). The protein concentration in the wells (1-12) was $1 \mathrm{mg} / \mathrm{mL}$, and $20 \mu \mathrm{L}$ was added to each well. Antivenom added to the middle well was $20 \mu \mathrm{L}$, containing a concentration of $1 \mathrm{mg} / \mathrm{mL}$ Lowry's protein. Several precipitin lines at each location pointed out the polyvalent character of the antibodies. The antibody titer augmented after the booster dose, and antibodies were present 180 days after the first injection. 


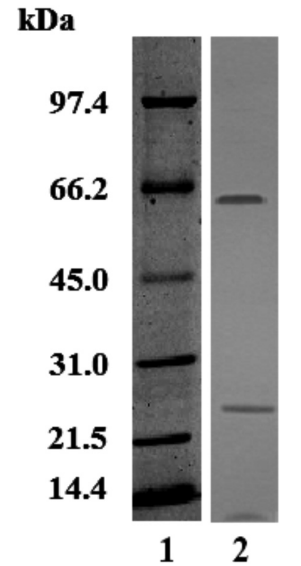

Fig. 2 - SDS-PAGE analysis (15\% gel concentration, under reducing conditions) of IgY Antibodies after precipitation with ammonium sulfate and dialysis. 1) Molecular weight markers. 2) IgY.

Serum protection test (Median effective dose $\left.=\mathbf{E D}_{50}\right)$ : Coral snake antivenom (IgY) was able to effectively neutralize the pool of all Micrurus isozonus coral snake venom used in the immunization with a mean $\mathrm{ED}_{50}$ of $477.8 \mathrm{mg} / \mathrm{kg}$ (Table 2).

Specificity of coral snake antivenom (IgY) to various snake venom via Western blot: The coral snake antivenom was able to recognize, to some degree, all the coral snake venoms used in this study in addition to two cobra snake venoms and three Venezuelan pit vipers. The antivenom was most specific to M.f. fulvius followed by M. isozonus, M. t. tener and M. surinamensis. The two Naja spp. had similar reactions to each other, and the two Crotalus spp. also showed similarities. Bothrops colombiensis venom had a different reactivity pattern than the other Venezuelan venom. Micrurus surinamensis venom had the least reaction with the antivenom compared to all the venom tested. No protein bands below $12 \mathrm{kDa}$ were detected for any venom.

\section{DISCUSSION}

Despite the significant pressure due to death and grave consequences

Effective dose fifty $\left(\mathrm{ED}_{50}=477 \mathrm{mg} / \mathrm{kg} / 3 \mathrm{LD}_{50}\right)$ assay of yielded antibodies (IgY coral snake antivenom neutralizing lethal toxic activity of coral snake venom

\begin{tabular}{|c|c|c|c|c|c|}
\hline \multirow{2}{*}{$\begin{array}{l}\text { Antivenom concentration } \\
(\mathrm{mg} / \mathrm{mL})\end{array}$} & \multirow{2}{*}{$\begin{array}{c}\text { Total protein of } \\
\text { antivenom (mg/mouse) }\end{array}$} & \multicolumn{3}{|c|}{ Number of mice } & \multirow{2}{*}{ Percentage of deaths $(\%)$} \\
\hline & & Died & Lived & Total & \\
\hline 86 & 17.2 & 0 & 8 & 8 & 0 \\
\hline 43 & 8.6 & 4 & 4 & 8 & 50 \\
\hline 21.5 & 4.3 & 8 & 0 & 8 & 100 \\
\hline 10.7 & 21.5 & 8 & 0 & 8 & 100 \\
\hline 5.3 & 5.3 & 8 & 0 & 8 & 100 \\
\hline
\end{tabular}

$$
\mathrm{ED}_{50}=477 \mathrm{mg} / \mathrm{kg}^{\mathrm{a}}
$$

resulting from accidents with coral snakes, the research and investment of funds for the production of antivenoms is considered insufficient. On the other hand, biochemical studies relating to Micrurus venoms are limited, due to the complexity of accurately identifying the species, the difficulties in maintaining them in captivity, and the difficulty in obtaining a desirable amount of venom; in addition, venom varies between intra and interspecies in composition, associated with their age, gender, geographic distribution, and $\operatorname{diet}^{4,10}$.

In this study, the competence of hens to make antibodies against small quantities of antigens was studied. In some conditions, there may be problems with getting adequate amounts of antigen to make immunizations. In this experiment the hens were immunized with 0.1 $100 \mu \mathrm{g}$ of antigen with booster immunizations. Every two weeks for eight weeks, the IgY response in the yolk demonstrated a similar picture as that in the serum. The study confirmed that it is possible to obtain a good immune response with less amounts of antigen than is usually recommended to immunize sheep or horses. Studies by some groups have established that antibody responses to foreign antigens are genetically controlled. It has been feasible to breed hens that are high and low antibody responders intramuscularly ${ }^{20}$ or by intravenous ${ }^{9,16}$ injections.

The $\mathrm{ED}_{50}$ was calculated according to Spearman and Karber ${ }^{31}: \log \mathrm{ED}_{50}=\log \mathrm{X}_{100}-\frac{\log \mathrm{FD}}{\mathrm{n}}(\Sigma \mathrm{t}-\mathrm{n} / 2)$

$\mathrm{ED}_{50}=$ the $50 \%$ effective dose. $\log \mathrm{X}_{100}=\log$ dose giving $100 \%$ survival and having $100 \%$ survival for all higher doses. $\log \mathrm{Fd}=$ the log dilution factor. $\mathrm{N}=\#$ mice used at each dose level. $\mathrm{T}=$ \#mice alive at each dose level. $\Sigma=$ the sum of mice surviving at every dose level. ${ }^{a} \mathrm{The} \mathrm{ED}_{50}$ is the effective dose of IgY that will protect $50 \%$ of the mouse population when injected with $3 \mathrm{LD}_{50} \mathrm{~s}$. 
AGUILAR, I.; SÁNCHEZ, E.E.; GIRÓN, M.E.; ESTRELLA, A.; GUERRERO, B. \& RODRIGUEZ-ACOSTA, F.A. - Coral snake antivenom produced in chickens (Gallus domesticus). Rev. Inst. Med. Trop. Sao Paulo, 56(1): 61-6, 2014

The production of IgY from small amounts of antigen required for immunization, the ease in collecting the eggs, and the uncomplicated purification techniques to enhance the function of immunological assays, make the use of IgY attractive and profitable.

Normally, antivenoms are achieved by immunizing horses with increasing doses of venom to obtain a high-quality antibody titer ${ }^{8}$. A range of side effects exists in the administration of antivenom; for instance, anaphylaxis and serum sickness ${ }^{27}$. The elevated concentrations of proteins, which are not antibodies, existing in many common antivenom probably produce most of these symptoms. With the aim of eliminating the unpleasant effects of the antivenom treatment, it is necessary to achieve antivenom immunoglobulins in a reasonable purification state. Investigators ${ }^{24,25,30}$ have proposed that birds are a suitable and economical supply of IgY immunoglobulins. Chicken egg yolks have Ig Y, which is a species-specific immunoglobulin with a molecular weight of $190 \mathrm{kDa}^{26}$. Our laboratory has produced hen antibodies against Scolopendra gigantea toxins with high titers ${ }^{19}$. Others have reported the production of immunoglobulins against different types of protein antigens, synthetic peptides, etc. ${ }^{29}$. We have improved the production of polyclonal antibodies by means of crude coral snake venom injected in hens with an alternative protocol, from that of the classical method used for horse immunoglobulin production. In our current work, we were capable of obtaining a good antibody titer with immunized hens.

Due to the high incidences of coral snake envenomations by $M$. isozonus in Venezuela, this particular snake venom was used to carry out the in vivo efficacy test of coral snake IgY antivenom, which resulted in $\mathrm{ED}_{50}$ of $477 \mathrm{mg} / \mathrm{kg}$ body weight (Table 2). This value falls within acceptable $\mathrm{ED}_{50}$ ranges of other antivenoms tested on different snake venoms ${ }^{7}$. A Western blot was done to determine the specificity of the IgY antivenom to different coral snake venoms as well as other Venezuelan venomous species. It appears that the $\operatorname{IgY}$ coral snake venom antivenom was able to recognize all four coral snake venoms used in the immunization protocol with $M$. isozonus, M. surinamensis, M.f. fulvius and M. t. tener having the highest recognition. The venom of $M$. surinamensis was the least reactive (Fig. 4). In addition to those venoms used to produce the IgY antivenom, two cobra venoms ( N. kaouthia and N. pallida), and three Venezuelan Viperidae species (B. colombiensis, $C$. d. cumanensis and $C$. vegrandis) were also detected by the antivenom. This cross reactivity suggests there are similar venom toxins found in species of snakes located in distinct geographical locations. The fact that M. surinamensis had the least reactivity of all venoms, including those not used in the immunization protocol, indicates the uniqueness of the proteins found in that venom. The possible use of $\operatorname{IgY}$ in therapy and/or diagnostic assays either in humans or animals provides an invaluable field of interesting and useful applications ${ }^{12,17,28}$.

\section{RESUMEN}

\section{Antiveneno de serpiente coral producido en gallinas (Gallus domesticus)}

La producción de antiveneno de serpiente usando sangre de grandes mamíferos se ha encontrado que es de bajo rendimiento y de trabajo arduo, en consecuencia, las inmunoglobulinas antiveneno para el tratamiento se obtienen generalmente, como suero polivalente. Hemos estandarizado una técnica poco exigente para la fabricación de inmunoglobulina purificada IgY, que consistió en generar anticuerpos policlonales contra el veneno de
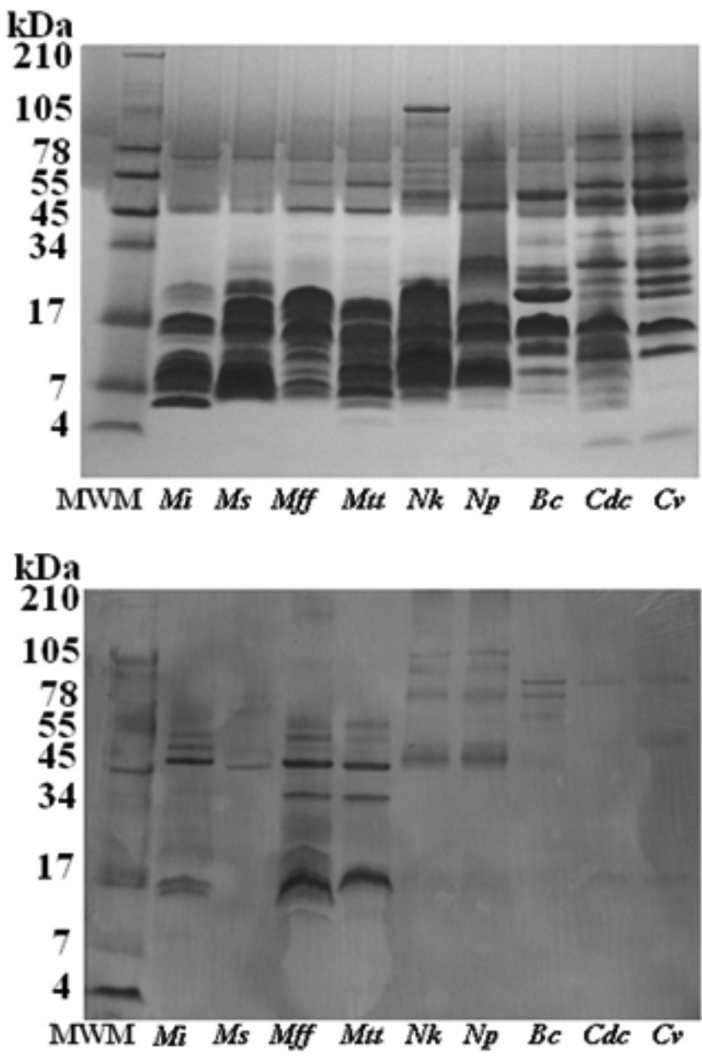

Fig. 4 - Gel electrophoresis and Western blot analysis of various snake venoms with IgY antibodies. A total of nine venoms (22 $\mu \mathrm{g} / \mathrm{each})$ consisting of $M$. isozonus (Mi), $M$. surinamensis (Ms), M. f. fulvius (Mff), M. t. tener (Mtt), Naja kaouthia (Nk), Naja pallida $(\mathrm{Np})$, Bothrops colombiensis (Bs), Crotalus durissus cumanensis $(\mathrm{Cdc})$ and $C$. vegrandis (Cv) were electrophoresed on a 10-20\% Tricine SDS gel using a XCell SureLock ${ }^{\mathrm{TM}}$ system at $150 \mathrm{~V}$ (Bio-Rad PowerPac Basic) for 1h. The proteins were transferred onto a $0.2 \mu \mathrm{m}$ nitrocellulose membrane (Millipore) using a Trans Blot SD system (BioRad) at $100 \mathrm{~mA}$ for 1 h. SIGMA FAST ${ }^{\mathrm{TM}}$ BCIP/NBT tablets were used to visualize the bands on the blot and SimplyBlue (Life Techonologies) was used to visualize the bands on the gel. SeeBluePlus2 (Life Techonologies) markers were used as standards.

la serpiente coral en huevos de gallinas inmunizadas. La técnica consistió en la eliminación de lípidos de las yemas del huevo, diluidas en agua y en una secuencia de congelación-descongelación. Las inmunoglobulinas específicas estuvieron presentes en la yema de huevo hasta 180 días después de la inmunización. La unión del antígeno a las inmunoglobulinas se detectó mediante un ensayo de inmunodifusión doble. Los títulos de anticuerpos en la yema fueron estimados con un ensayo de protección (dosis efectiva media $=\mathrm{ED} 50$ ). . Dado que las gallinas reproductoras son económicamente viables, la recolección de huevos es no invasiva y la purificación de anticuerpos IgY es rápida y fácil, la inmunización de la gallina es una excelente alternativa para la producción de anticuerpos policlonales. A nuestro entender, esta es el primer anti-veneno contra serpiente de coral preparado en aves.

\section{ACKNOWLEDGEMENTS}

Foundation Project: This research was supported by grants from the FONACIT (Venezuela)(G-2005000400), Shell Venezuela S.A, Ministry of the Popular Power for Science and Technology (LOCTI program), CDCH/UCV PG: 09-8760-2013/1, and the Natural Toxins 
AGUILAR, I.; SÁNCHEZ, E.E.; GIRÓN, M.E.; ESTRELLA, A.; GUERRERO, B. \& RODRIGUEZ-ACOSTA, F.A. - Coral snake antivenom produced in chickens (Gallus domesticus). Rev. Inst. Med. Trop. Sao Paulo, 56(1): 61-6, 2014.

Research Center and Department of Chemistry at Texas A\&M UniversityKingsville, Kingsville, Texas, USA.

\section{AUTHOR CONTRIBUTIONS}

Irma Aguilar is a Ph.D student who worked on the immunization of animals and purified the IgYs. She was involved in all the experiments done. Elda E. Sánchez developed the $\mathrm{LD}_{50}$ and $\mathrm{ED}_{50}$ assays, the gel electrophoresis and Western blot of the various snake venoms with the $\mathrm{I}_{\mathrm{g}} \mathrm{G}$ antibodies as well as collaborated with the writing of the manuscript. María E. Girón and Amalid Estrella are Research Assistants who did the general experiments. Belsy Guerrero carried out the electrophoresis and Western blot as well as collaborated with the writing of the manuscript. Alexis Rodriguez-Acosta designed and supervised the project and wrote the manuscript. He is the thesis tutor of MSc. Aguilar.

\section{CONFLICT OF INTEREST STATEMENT}

We declare that we have no conflict of interest. Authors transfer the copyright of the article to the publisher.

\section{REFERENCES}

1. Almeida CM, Kanashiro MM, Rangel Filho FB, Mata MF, Kipnis TL, da Silva WD. Development of snake antivenom antibodies in chickens and their purification from yolk. Vet Rec. 1998;143:579-84.

2. Araújo AS, Lobato ZI, Chávez-Olórtegui C, Velarde DT. Brazilian IgY-Bothrops antivenom: studies on the development of a process in chicken egg yolk.Toxicon. 2010; 55:739-44

3. Campbell JA, Lamar WW. The venomous reptiles of Latin America. Ithaca: Cornell University Press; 1989.

4. Chippaux JP, Williams V, White J. Snake venom variability methods of study, results and interpretation. Toxicon. 1991;29:1279-303.

5. Christensen PA. Production and standardization of antivenin. In: Lee CY, editor. Handbook of experimental pharmacology. New York: Springer-Verlag; 1979. p. 1-825.

6. Consroe P, Egen NB, Russell FE, Gerrish K, Smith DC, Sidki A, et al. Comparison of a new ovine antigen binding fragment (Fab) antivenin for United States Crotalidae with the commercial antivenin for protection against venom-induced lethality in mice. Am J Trop Med Hyg. 1995;53:507-10.

7. Devi CM, Bai MV, Lal AV, Umashankar PR, Krishnan LK. An improved method for isolation of anti-viper venom antibodies from chicken egg yolk. J Biochem Biophys Methods. 2002;51:129-38

8. Estrada R, Chaves F, Robles A, Rojas E, Segura E, Gutiérrez JM. Valores hematológicos y de enzimas séricas en caballos inoculados com venenos de serpientes para la producción de antivenenos en Costa Rica. Rev Biol Trop. 1992;40:95-9.

9. Gross WG, Siegel PB, Hall RW, Domermuth CH, DuBoise RT. Production and persistence of antibodies in chickens to sheep erythrocytes. 2. Resistance to infectious diseases. Poult Sci. 1980;59:205-10.

10. Gutiérrez JM, Chaves F, Rojas R, Bolaños R. Efectos locales inducidos por el veneno de la serpiente coral Micrurus nigrocinctus en Ratón Blanco. Toxicon. 1980;18:633-9.

11. Gutiérrez JM, Rojas E, Quesada L, Léon G, Núñez J, Laing GD, et al. Pan-African polyspecific antivenom produced by caprylic acid purification of horse IgG: an alternative to the antivenom crisis in Africa. Trans R Soc Trop Med Hyg. 2005;99:46875 .

12. Hernández-Campos FJ, Brito-De la Fuente E, Torrestiana-Sánchez B. Purification of egg yolk immunoglobulin ( $\operatorname{IgY}$ ) by ultrafiltration: effect of $\mathrm{pH}$, ionic strength, and membrane properties. J Agric Food Chem. 2010;58:187-93.
13. Institute of Laboratory Animal Resources. Guide for the care and use of laboratory animals. $8^{\text {th }}$ ed. Washington: National Research Council, National Academies Press; 2011.

14. Laemmli UK. Cleavage of structural proteins during the assembly of the head of bacteriophage T4. Nature. 1970;227:680-5.

15. Lowry OH, Rosebrough NJ, Farr AL, Randall RJ, Protein measurement with the Folin phenol reagent. J Biol Chem. 1951;193:265-75.

16. Martin A, Dunnington EA, Gross WB, Briles WE, Briles RW, Siegel PB. Production traits and alloantigen systems in lines of chickens selected for high or low antibody responses to sheep erythrocytes. Poult Sci. 1990;69:871-8.

17. Meenatchisundaram S, Parameswari G, Michael A, Ramalingam S. Studies on pharmacological effects of Russell's viper and Saw-scaled viper venom and it neutralization by chicken egg yolk antibodies. Int Immunopharmacol. 2008;8:106773.

18. Ouchterlony O. Diffusion-in-gel methods for immunological analysis. Prog Allergy. 1958;5:1-78.

19. Parrilla P, Navarrete LF, Girón M.E, Aguilar I, Rodríguez-Acosta A. Use of chicken egg yolk-derived immunoglobulin against Scolopendra venom as an alternative to treat scolopendrism. Rev Cient FCV-LUZ. 2008;18:385-92.

20. Pinard MH, van Arendonk JA, Nieuwland MG, van der Zijpp AJ. Divergent selection for immune responsiveness in chickens: estimation of realized heritability with an animal model. J Anim Sci. 1992;70:2986-93.

21. Prieto da Silva AR, Yamagushi IK, Morais JF, Higashi HG, Raw I, Ho PL, et al. Cross reactivity of different specific Micrurus antivenom sera with homologous and heterologous snake venoms. Toxicon. 2001;39:949-53.

22. Roze JA. Coral snakes of the Americans. Biology, identification, and venoms. Florida Krieger Publishing Co; 1996.

23. Sánchez EE, Lopez-Johnston JC, Rodríguez-Acosta A, Pérez JC. Neutralization of two North American coral snake venoms with United States and Mexican antivenoms. Toxicon. 2008;51:297-303.

24. Sells PG, Laing GD, Theakston RD. An in vivo but insensate model for the evaluation of antivenoms (ED50) using fertile hens' eggs. Toxicon. 2001;39:665-8.

25. Schade R, Calzado EG, Sarmiento R, Chacana PA, Porankiewicz-Asplund J, Terzolo HR Chicken egg yolk antibodies (IgY-technology): a review of progress in production and use in research and human and veterinary medicine. Altern Lab Anim. 2005;33:12954.

26. Schade R, Schniering A, Hlinak A. Polyclonal avian antibodies extracted from egg yolk as an alternative to the production of antibodies in mammals: a review. ALTEX 1992; 9:43-56.

27. Schellekens H. How to predict and prevent the immunogenicity of therapeutic proteins Biotechnol Annu Rev. 2008;14:191-202.

28. Spillner E, Braren I, Greunke K, Seismann H, Blank S, du Plessis D. Avian IgY antibodies and their recombinant equivalents in research, diagnostics and therapy. Biologicals. 2012;40:313-22.

29. Stuart CA, Pietrzyk RA, Furlanetto RW, Green A. High affinity antibody from hen's eggs directed against the human insulin receptor and the human IGF-I receptor. Ana Biochem. 1988; 173:142-50.

30. Svendson L, Crowley A, Ostergaard LH, Stodulski G, Hau J. Development and comparison of purification strategies for chicken antibodies from egg yolk. Lab Anim Sci. 1995;45:89-3.

31. World Health Organization. Progress in the characterization of venoms and standardization of antivenoms. Who Offset Publ. 1981;58:1-44

Received: 9 April 2013

Accepted: 6 June 2013 